\title{
Understanding Activity Participation in Children with Physical Disabilities in Korea
}

\author{
Se-Yun Kim \\ Dept. of Physical Therapy, Woosuk University, Korea \\ ksy8024@woosuk.ac.kr
}

\begin{abstract}
This study aims to identify the diversity and intensity of participation of school-aged children with physical disabilities and to investigate the effects of individual and family variables on the participation intensity. The Activity Participation Assessment (APA) was conducted on 93 children with physical disabilities aged 7-15 years to assess the diversity and intensity of participation. The research result are as follows. First, children with physical disabilities participated in more Activity of Daily Living (ADL), instrument ADL, and craft. Second, the intensity of participation of children with physical disabilities was 1.56 (SD 0.41) on average for APA all domains. Third, sex differences were found in sports $(p<0.01)$, children over 14 years were significantly lower than those of other groups in both the diversity and intensity of participation. Fourth, the higher the disability rating, the lower the number of multiple disabilities, children took part in greater numbers of activities $(p<0.01)$ and higher frequency in all domains except ADL domain ( $p<0.01$ ). Finally, the higher the educational level of caregiver, the higher the participation frequency of children $(p<0.05)$.
\end{abstract}

Keywords: Child, Participation, Physical disability, School-age

\section{Introduction}

Participation is considered as the key to the child's development, health and quality of life [1]. Children learn the skills, form friendship, acquire intellectual and physical health, express creativity and develop their self-identity through participation. Children with disabilities tend to be less engaged in leisure and social activities than children in general, and the diversity of participation decreases rapidly as adolescence [2]. Children with disabilities are limited participation in various activities compared to children without disability.

Physical access, family factors (family income and family function) and children factors (cognitive ability and social skills) can be considered as factors influencing the leisure and recreational activities of children with physical disabilities [3]. As a result of analyzing the participation patterns of leisure and recreational activities of children with multiple physical disabilities, they reported that children with physical disabilities participated in informal activities more than formal activities and were influenced participation by family variables [4]. Children with cerebral palsy limited self-mobility had lower levels of participation than those with independent mobility. Children's factors such as motor function, adaptive behavior, transfers and mobility function, upper extremity and physical function was correlated with the level of participation [5].

Article history:

Received (September 28, 2019), Review Result (November 2, 2019), Accepted (December 22, 2019) 
Although the participation of children with disabilities is known to be influenced by various variables, there is a lack of research on factors affecting the participation of schoolaged children with disabilities in Korea. The above previous studies examined participation patterns with a focus on leisure and recreational activities of children with disabilities. There are limited studies analyzed factors affecting school-age children's other activities in addition to leisure activities.

Therefore, the purpose of this study was to investigate the diversity and intensity of participation and explore the causal relationship between individual variables, family variables and participation characteristics of school-aged children with physical disabilities in Korea.

\section{Method}

\subsection{Participants}

The participants of this study were 93 children aged 8-15 attending elementary school with physical disabilities and their caregivers. The mean age of participants were 9.7 years $(\mathrm{SD}=$ 0.57). General characteristics of the subjects are shown in [Table 1]. The subjects included 27 children with cerebral palsy, 36 children with brain lesions, 20 developmental delays, 5 musculoskeletal disorders, and 5 others (dermatomyositis, spinal cord injury, and chromosomal disease). Disability rating 1 was the highest in 43 children (46.2\%), disability rating 2 was 16 children, both disability rating 3 and 4 were 17 children, with no disability rating 5-6. Multiple disabilities were checked by overlapping responses. Among the disability type, 58 children with motor disability is most. Forty-six children (49.5\%) had one multiple disabilities.

Table 1. Characteristics of children with physical disability ( $\mathrm{N}=93$ )

\begin{tabular}{|c|c|c|}
\hline Characteristic & & $\mathrm{N}(\%)$ \\
\hline \multirow{2}{*}{ Sex } & Boy & $51(54.8)$ \\
\hline & Girl & $42(45.2)$ \\
\hline \multirow{3}{*}{ Age group } & 8-10 years of age & $58(62.4)$ \\
\hline & $11-13$ years of age & $15(16.1)$ \\
\hline & Over 14 years of age & $20(21.5)$ \\
\hline \multirow{5}{*}{$\begin{array}{c}\text { Primary health/ } \\
\text { development problem }\end{array}$} & Cerebral palsy & $27(29.0)$ \\
\hline & Brain disorder & $36(38.7)$ \\
\hline & Developmental delay & $20(21.5)$ \\
\hline & Muscluoskeletal system & $5(5.4)$ \\
\hline & Other & $5(5.4)$ \\
\hline \multirow{4}{*}{ Disability rating } & 1 & $43(46.2)$ \\
\hline & 2 & $16(17.2)$ \\
\hline & 3 & $17(18.3)$ \\
\hline & 4 & $17(18.3)$ \\
\hline \multirow{5}{*}{$\begin{array}{c}\text { Type of multiple } \\
\text { disabilities(duplicate } \\
\text { response) }\end{array}$} & Intellectual disability & 55 \\
\hline & Verbal disability & 51 \\
\hline & Sensory disability & 22 \\
\hline & Motor disability & 58 \\
\hline & Other & 8 \\
\hline \multirow{4}{*}{$\begin{array}{l}\text { Number of multiple } \\
\text { disabilities }\end{array}$} & 1 & $46(49.5)$ \\
\hline & 2 & $11(11.8)$ \\
\hline & 3 & $17(18.3)$ \\
\hline & 4 & $19(20.4)$ \\
\hline
\end{tabular}


General characteristics of the caregivers are shown in [Table 2]. Most of the caregivers respondents were mothers (77.4\%) and the most age of caregiver was 40 49 (57.0\%). More than $70 \%$ of the caregivers were at least college graduates. The family income of 30.0 39.9 million won was at $30.1 \%$ of the sample. The largest number of caregivers was in small and medium-sized cities $(69.9 \%)$.

Table 2. Caregiver Demographic Information (N=93)

\begin{tabular}{|c|c|c|}
\hline Characteristic & & $\mathrm{N}(\%)$ \\
\hline \multirow{4}{*}{ Relationship to the child } & Father & $8(8.6)$ \\
\cline { 2 - 3 } & Mother & $72(77.4)$ \\
\cline { 2 - 3 } & Grandparents & $2(2.2)$ \\
\cline { 2 - 3 } & Other & $11(11.8)$ \\
\hline \multirow{4}{*}{ Age } & $20 \sim 29$ & $4(4.3)$ \\
\cline { 2 - 3 } & $30 \sim 39$ & $28(30.1)$ \\
\cline { 2 - 3 } & $40 \sim 49$ & $53(57.0)$ \\
\cline { 2 - 3 } & $50 \sim 59$ & $6(6.5)$ \\
\hline \multirow{4}{*}{ Education level of caregiver } & $60 \sim 69$ & $2(2.2)$ \\
\cline { 2 - 3 } & Less than high school & $4(4.3)$ \\
\cline { 2 - 3 } & High school & $22(23.7)$ \\
\cline { 2 - 3 } & Associate's graduate & $18(19.4)$ \\
\cline { 2 - 3 } & Bachelor's degree & $41(44.1)$ \\
\hline \multirow{5}{*}{ Family income } & Master's degree & $8(8.6)$ \\
\cline { 2 - 3 } & Less than 2 million(won) & $20(21.5)$ \\
\cline { 2 - 3 } & 2-2.99 million(won) & $14(15.1)$ \\
\cline { 2 - 3 } & 3-3.99 million(won) & $28(30.1)$ \\
\cline { 2 - 3 } & 4-4.99 million(won) & $10(10.8)$ \\
\cline { 2 - 3 } & Over 5 million(won) & $21(22.6)$ \\
\hline \multirow{5}{*}{ Type of community } & Metropolitan & $22(23.7)$ \\
\cline { 2 - 3 } & Small and medium cities & $65(69.9)$ \\
\cline { 2 - 3 } & Agricultural, mountain and fishing & $6(6.5)$ \\
\hline & villages & \\
\hline
\end{tabular}

\subsection{Measurement}

The Activity Participation Assessment (APA) was used to assess all participants' activity participation. The APA consisted of 30 activities in 8 domains. Each activity is recorded as 1 point 'not at all', 2 points at 'sometimes' (more than once every 3 months), and 3 points at 'very frequent' (almost every day) depending on how often the child participates. Higher scores indicate higher intensity of participation. As a result of exploratory factor analysis, it was classified into 8 factors and 30 activities. The internal reliability of each factor ranged from .70 to .91 Cronbach's alpha value [6].

\subsection{Procedure}

The subjects of this study were 93 children with physical disabilities. We sent letters to six physically handicapped schools for permission and conducted a questionnaire. We explained the purpose and procedures of the study to the caregivers and asked for consent. The researcher and the research assistant collected a total of 93 questionnaires by surveying the caregivers of the children who agreed to the study.

\subsection{Data analysis}


Descriptive statistics analysis was conducted to find basic statistics such as the general characteristics of children and caregivers, participation diversity and intensity of the children. An analysis of variance was used to examine the relationship between participation characteristics and individual variables of children with physical disabilities. The correlation between participation characteristics and family variables of children with physical disabilities was examined through the Pearson correlation coefficient. Statistical analysis was conducted by SPSS 25.0.

\section{Result}

\subsection{Participation diversity (number of activities done)}

As a result of analyzing the participation diversity of children with physical disabilities, they participated in more various activities in the ADL, IADL, craft, and artistic activity domains, and proportionally less in the sports and winter domains [Table 3]. Sex differences were found in IADL $(\mathrm{p}<0.05)$ and sports $(\mathrm{p}<0.01)$ and differences between age group were found in IADL ( $\mathrm{p}<0.05)$, social activity ( $\mathrm{p}<0.05)$, craft ( $\mathrm{p}<0.01)$, artistic activity $(\mathrm{p}<0.01)$, play ( $\mathrm{p}<0.01$ ), and sports $(\mathrm{p}<0.05)$. In all activity domains except ADL, the higher the disability rating and the lower the number of multiple disabilities, the more they participated in various activities $(\mathrm{p}<0.01)$.

Table 3. Participation diversity/number of activities done $(\mathrm{N}=93)$

\begin{tabular}{|c|c|c|c|c|c|c|c|c|c|c|c|}
\hline \multicolumn{3}{|c|}{ Participation frequency } & $\begin{array}{c}\text { Total } \\
\text { (30 items) }\end{array}$ & $\begin{array}{c}\text { ADL } \\
\text { (2 items) }\end{array}$ & $\begin{array}{l}\text { IADL } \\
\text { (8 items) }\end{array}$ & $\begin{array}{c}\text { Social } \\
\text { Activities } \\
(4 \text { items })\end{array}$ & $\begin{array}{c}\text { Craft } \\
\text { Activities } \\
\text { (5items) }\end{array}$ & $\begin{array}{l}\text { Artistic } \\
\text { activities } \\
\text { (3items) }\end{array}$ & $\begin{array}{c}\text { Play } \\
\text { activities } \\
(2 \text { items })\end{array}$ & $\begin{array}{l}\text { Sports } \\
\text { activities } \\
\text { (4 items) }\end{array}$ & $\begin{array}{l}\text { Winter } \\
\text { activities } \\
(2 \text { items })\end{array}$ \\
\hline \multicolumn{2}{|c|}{ Total $(\mathrm{N}=93)$} & $\begin{array}{c}\text { Mean } \\
\text { (SD) }\end{array}$ & $14.05(10.59)$ & $1.28(0.93)$ & $4.75(5.20)$ & $1.30(1.41)$ & $4.06(1.44)$ & $1.95(1.18)$ & $0.97(0.90)$ & $0.69(1.04)$ & $0.41(0.74)$ \\
\hline \multirow{2}{*}{ Sex } & $\begin{array}{c}\text { Boy } \\
(n=51)\end{array}$ & $\begin{array}{c}\text { Mean } \\
\text { (SD) }\end{array}$ & $14.65(11.14)$ & $1.25(0.96)$ & $5.20(5.67)^{*}$ & $1.31(1.46)$ & $2.88(2.01)$ & $1.84(1.19)$ & $0.98(0.91)$ & $0.80(1.22)^{* *}$ & $0.37(0.72)$ \\
\hline & $\begin{array}{c}\text { Girl } \\
(\mathrm{n}=42)\end{array}$ & $\begin{array}{l}\text { Mean } \\
(\mathrm{SD})\end{array}$ & 13.33(9.97) & $1.31(0.90)$ & $4.21(4.58)$ & $1.29(3.13)$ & $2.50(2.12)$ & $2.07(1.18)$ & $0.95(0.91)$ & $0.55(0.77)$ & $0.45(0.77)$ \\
\hline \multirow{3}{*}{ Age } & $\begin{array}{c}8-10 \\
(\mathrm{n}=58)\end{array}$ & $\begin{array}{l}\text { Mean } \\
\text { (SD) }\end{array}$ & $16.00(10.98)^{*}$ & $1.38(0.90)$ & $5.40(564)^{*}$ & $1.43(1.45)^{*}$ & $3.16(1.97)^{* *}$ & $2.17(1.09)^{* *}$ & $1.26(0.83)^{* *}$ & $0.76(1.08)^{*}$ & $0.45(0.78)$ \\
\hline & $\begin{array}{c}11-13 \\
(n=15)\end{array}$ & $\begin{array}{l}\text { Mean } \\
\text { (SD) }\end{array}$ & $17.80(7.99)$ & $1.27(0.96)$ & $6.07(4.30)$ & $1.80(1.52)$ & $3.60(1.40)$ & $2.47(0.83)$ & $0.93(0.96)$ & $1.07(1.22)$ & $0.60(0.91)$ \\
\hline & $\begin{array}{c}>13 \\
(\mathrm{n}=20)\end{array}$ & $\begin{array}{l}\text { Mean } \\
\text { (SD) }\end{array}$ & $5.60(6.05)$ & $1.00(0.97)$ & $1.90(3.28)$ & $0.55(0.83)$ & $0.75(1.48)$ & $0.90(1.07)$ & $0.15(0.49)$ & $0.20(0.52)$ & $0.15(0.37)$ \\
\hline \multirow{4}{*}{$\begin{array}{l}\text { Disability } \\
\text { rating }\end{array}$} & $1(n=43)$ & $\begin{array}{l}\text { Mean } \\
\text { (SD) }\end{array}$ & $6.00(5.16)^{* *}$ & $1.09(0.97)$ & $1.21(2.05)^{* *}$ & $0.49(0.74)^{* *}$ & $1.33(1.67)^{* *}$ & $1.33(1.17)^{* *}$ & $0.42(0.70)^{* *}$ & $0.07(0.26)^{* *}$ & $0.07(0.26)^{* *}$ \\
\hline & $2(n=16)$ & $\begin{array}{c}\text { Mean } \\
\text { (SD) }\end{array}$ & 20.94(10.36) & $1.31(0.95)$ & $6.88(4.95)$ & $2.44(1.46)$ & $3.94(1.77)$ & $2.50(0.82)$ & $1.38(0.89)$ & $1.38(1.26)$ & $1.13(0.96)$ \\
\hline & $3(n=17)$ & $\begin{array}{l}\text { Mean } \\
\text { (SD) }\end{array}$ & $20.88(7.61)$ & $1.47(0.80)$ & $9.47(5.15)$ & $1.29(1.16)$ & $3.71(1.57)$ & $2.47(1.01)$ & $1.35(0.79)$ & $0.94(0.90)$ & $0.18(0.39)$ \\
\hline & $4(n=17)$ & $\begin{array}{l}\text { Mean } \\
\text { (SD) }\end{array}$ & $21.12(9.62)$ & $1.53(0.87)$ & $7.00(5.26)$ & $2.29(1.57)$ & $6.53(1.94)$ & $2.47(0.84)$ & $1.59(0.71)$ & $1.35(1.32)$ & $0.82(0.95)$ \\
\hline \multirow{4}{*}{$\begin{array}{l}\text { Number of } \\
\text { multiple } \\
\text { disabilities }\end{array}$} & $1(n=46)$ & $\begin{array}{l}\text { Mean } \\
\text { (SD) }\end{array}$ & $19.57(10.25)^{*}$ & $1.52(0.81)$ & $7.09(5.51)^{* *}$ & $1.87(1.54)^{* *}$ & $3.61(1.80)^{* *}$ & $2.37(1.06)^{* *}$ & $1.33(0.85)^{* *}$ & $1.09(1.17)^{* *}$ & $0.70(0.87)^{* *}$ \\
\hline & $2(n=11)$ & $\begin{array}{c}\text { Mean } \\
\text { (SD) }\end{array}$ & $9.36(7.61)$ & $0.91(1.04)$ & $3.09(4.48)$ & $0.55(1.04)$ & $2.27(1.42)$ & $1.64(1.03)$ & $0.55(0.82)$ & $0.27(0.47)$ & $0.09(0.30)$ \\
\hline & $3(n=17)$ & $\begin{array}{l}\text { Mean } \\
\text { (SD) }\end{array}$ & $8.59(8.90)$ & $1.00(1.00)$ & $2.53(3.56)$ & $0.76(1.03)$ & $1.65(2.23)$ & $1.53(1.28)$ & $0.65(0.86)$ & $0.29(0.77)$ & $0.18(0.53)$ \\
\hline & $4(n=19)$ & $\begin{array}{l}\text { Mean } \\
\text { (SD) }\end{array}$ & $8.32(7.36)$ & $1.16(0.96)$ & $2.05(3.46)$ & $0.84(0.96)$ & $1.74(1.97)$ & $1.47(1.17)$ & $0.63(0.83)$ & $0.32(0.82)$ & $0.11(0.46)$ \\
\hline
\end{tabular}

\subsection{Participation intensity (frequency)}


The participation intensity of children with disabilities was mean 1.56 (SD 0.41) in all APA activities. Across the eight activity domains, children took part in the ADL domain at an average of 2.40 (SD 0.83), while they participated in the sports at an averaged 1.20 (SD 0.34). Boy participated in sports activities more frequently than girl. The total participation frequency of children over the age of 14 was lower than that of other age groups $(p<0.01)$. Except for ADL domain, the higher the disability rating and the lower the number of multiple disorders, the higher the frequency of participation $(p<0.01)$ [Table 4].

Table 4. Participation intensity (frequency)

\begin{tabular}{|c|c|c|c|c|c|c|c|c|c|c|c|}
\hline \multicolumn{3}{|c|}{ Participation frequency } & $\begin{array}{c}\text { Total } \\
(30 \text { items })\end{array}$ & $\begin{array}{c}\mathrm{ADL} \\
(2 \text { items })\end{array}$ & $\begin{array}{c}\text { IADL } \\
\text { (8 items) }\end{array}$ & $\begin{array}{c}\text { Social } \\
\text { activities } \\
\text { (4 items) }\end{array}$ & $\begin{array}{c}\text { Craft } \\
\text { activities } \\
\text { (8 items) }\end{array}$ & $\begin{array}{l}\text { Artistic } \\
\text { activities } \\
\text { (3 items) }\end{array}$ & $\begin{array}{c}\text { Play } \\
\text { activities } \\
\text { (2 items) }\end{array}$ & $\begin{array}{c}\text { Sports } \\
\text { activities } \\
\text { (4 items) }\end{array}$ & $\begin{array}{l}\text { Winter } \\
\text { activities } \\
\text { (2 items) }\end{array}$ \\
\hline \multicolumn{2}{|c|}{ Total $(\mathrm{N}=93)$} & $\begin{array}{c}\text { Mean } \\
\text { (SD) }\end{array}$ & $1.56(0.41)$ & $2.40(0.83)$ & $1.41(0.50)$ & $1.41(0.47)$ & $1.68(0.58)$ & $2.04(0.68)$ & $1.58(0.59$ & $1.20(0.34)$ & $1.22(0.41)$ \\
\hline \multirow{2}{*}{ Sex } & $\begin{array}{c}\text { Boy } \\
(\mathrm{n}=51)\end{array}$ & $\begin{array}{l}\text { Mean } \\
(\mathrm{SD})\end{array}$ & $1.58(0.45)$ & $2.37(0.85)$ & $1.47(0.54)^{*}$ & $1.43(0.53)$ & $1.72(0.58)$ & $1.96(0.67)$ & $1.59(0.61)$ & $1.25(0.41)^{*}$ & $1.21(0.43)$ \\
\hline & $\begin{array}{c}\text { Girl } \\
(\mathrm{n}=42)\end{array}$ & $\begin{array}{l}\text { Mean } \\
\text { (SD) }\end{array}$ & $1.53(0.36)$ & $2.43(0.80)$ & $1.35(0.44)$ & $1.39(0.41)$ & $1.62(0.57)$ & $2.13(0.70)$ & $1.56(0.58)$ & $1.15(0.23)$ & $1.23(0.39)$ \\
\hline \multirow{3}{*}{ Age } & $\begin{array}{c}8-10 \\
(\mathrm{n}=58)\end{array}$ & $\begin{array}{l}\text { Mean } \\
\text { (SD) }\end{array}$ & $1.64(0.44)^{* *}$ & $2.47(0.80)$ & $1.47(0.55)$ & $1.46(0.50)^{*}$ & $1.81(0.59)^{* *}$ & $2.17(0.65)^{* *}$ & $1.76(0.58)^{* *}$ & $1.24(0.38)$ & $1.24(0.44)$ \\
\hline & $\begin{array}{c}11-13 \\
(\mathrm{n}=15)\end{array}$ & $\begin{array}{l}\text { Mean } \\
\text { (SD) }\end{array}$ & $1.67(0.29)$ & $2.53(0.67)$ & $1.47(0.37)$ & $1.55(0.51)$ & $1.87(0.40)$ & $2.31(0.60$ & $1.53(0.58)$ & $1.28(0.33)$ & $1.30(0.46)$ \\
\hline & $\begin{array}{c}>13 \\
(\mathrm{n}=20)\end{array}$ & $\begin{array}{l}\text { Mean } \\
\text { (SD) }\end{array}$ & $1.24(0.23)$ & $2.08(0.95)$ & $1.21(0.37)$ & $1.16(0.26)$ & $1.16(0.32)$ & $1.45(0.51)$ & $1.07(0.24)$ & $1.05(0.13)$ & $1.08(0.18)$ \\
\hline \multirow{4}{*}{$\begin{array}{l}\text { Disability } \\
\text { rating }\end{array}$} & $1(n=43)$ & $\begin{array}{l}\text { Mean } \\
\text { (SD) }\end{array}$ & $1.28(0.22)^{* *}$ & $2.15(0.94)$ & $1.13(0.21)^{* *}$ & $1.15(0.23)^{* *}$ & $1.33(0.43)^{* *}$ & $1.73(0.66)^{* *}$ & $1.23(0.41)^{* *}$ & $1.02(0.06)^{* *}$ & $1.03(0.13)^{* *}$ \\
\hline & $2(n=16)$ & $\begin{array}{l}\text { Mean } \\
\text { (SD) }\end{array}$ & $1.83(0.47)$ & $2.56(0.63)$ & $1.59(0.57)$ & $1.75(0.55)$ & $2.09(0.62)$ & $2.33(0.57)$ & $1.78(0.58)$ & $1.42(0.51)$ & $1.63(0.59)$ \\
\hline & $3(n=17)$ & $\begin{array}{l}\text { Mean } \\
\text { (SD) }\end{array}$ & $1.70(0.24)$ & $2.68(0.56)$ & $1.67(0.39)$ & $1.41(0.43)$ & $1.85(0.41)$ & $2.29(0.61)$ & $1.74(0.44)$ & $1.25(0.23)$ & $1.09(0.20)$ \\
\hline & $4(n=17)$ & $\begin{array}{l}\text { Mean } \\
\text { (SD) }\end{array}$ & $1.85(0.44)$ & $2.59(0.80)$ & $1.71(0.67)$ & $1.75(0.52)$ & $2.04(0.49)$ & $2.29(0.61)$ & $2.09(0.62)$ & $1.43(0.40)$ & $1.41(0.48)$ \\
\hline \multirow{4}{*}{$\begin{array}{l}\text { Number of } \\
\text { Multiple } \\
\text { disabilities }\end{array}$} & $1(n=46)$ & $\begin{array}{l}\text { Mean } \\
\text { (SD) }\end{array}$ & $1.76(0.43)^{* *}$ & $2.63(0.68)$ & $1.62(0.58)^{* *}$ & $1.61(0.55)^{* *}$ & $1.95(0.56)^{* *}$ & $2.25(0.63)^{*}$ & $1.80(0.60)^{* *}$ & $1.34(0.41)^{* *}$ & $1.37(0.49)^{* *}$ \\
\hline & $2(\mathrm{n}=11)$ & $\begin{array}{l}\text { Mean } \\
\text { (SD) }\end{array}$ & $1.38(0.27)$ & $2.09(0.94)$ & $1.30(0.41)$ & $1.16(0.30)$ & $1.51(0.35)$ & $1.85(0.66)$ & $1.36(0.55)$ & $1.07(0.12)$ & $1.05(0.15)$ \\
\hline & $3(\mathrm{n}=17)$ & $\begin{array}{l}\text { Mean } \\
\text { (SD) }\end{array}$ & $1.36(0.32)$ & $2.18(0.90)$ & $1.19(0.23)$ & $1.24(0.30)$ & $1.42(0.58)$ & $1.88(0.77)$ & $1.38(0.55)$ & $1.07(0.19)$ & $1.09(0.26)$ \\
\hline & $4(n=19)$ & $\begin{array}{l}\text { Mean } \\
\text { (SD) }\end{array}$ & $1.33(0.24)$ & $2.21(0.92)$ & $1.18(0.26)$ & $1.22(0.25)$ & $1.36(0.41)$ & $1.77(0.62)$ & $1.32(0.42)$ & $1.08(0.21)$ & $1.05(0.23)$ \\
\hline
\end{tabular}

\subsection{Relationship between family variables and intensity of participation}

Among the family characteristics of children with physical disabilities, the relationship with children showed a significant correlation with ADL $(\mathrm{p}<0.05)$. The educational level of caregiver showed correlation with the participation intensity $(\mathrm{p}<0.05)$. The higher the family income, the higher the intensity of participation in winter activities $(\mathrm{p}<0.01)$, and the children living in larger cities participated more frequently in play activities $(\mathrm{p}<0.05)$.

Table 5. Correlations between family variables and intensity of participation

\begin{tabular}{|c|c|c|c|c|c|c|c|c|c|c|}
\hline \multirow{2}{*}{\multicolumn{2}{|c|}{ Characteristic }} & \multicolumn{9}{|c|}{ APA domain } \\
\hline & & & & & Social & Craft & Artistic & Play & Sports & Winter \\
\hline \multirow{3}{*}{ Family } & $\begin{array}{l}\text { Relationship to } \\
\text { the child }\end{array}$ & 0.08 & $0.25 *$ & 0.04 & 0.01 & 0.07 & 0.09 & -0.01 & 0.03 & 0.18 \\
\hline & Age & -0.18 & -0.04 & -0.15 & -0.16 & -0.14 & $-.23 *$ & -0.20 & -0.13 & 0.02 \\
\hline & $\begin{array}{c}\text { Education level of } \\
\text { caregiver }\end{array}$ & $0.25 *$ & 0.06 & 0.18 & $0.30 * *$ & 0.17 & $.23 *$ & $0.24 *$ & 0.18 & $0.32 * *$ \\
\hline
\end{tabular}




\begin{tabular}{|c|c|c|c|c|c|c|c|c|c|c|}
\hline & Family income & 0.13 & 0.01 & 0.11 & 0.15 & 0.04 & .06 & 0.12 & 0.17 & $0.30^{* *}$ \\
\cline { 2 - 8 } & $\begin{array}{c}\text { Type of } \\
\text { community }\end{array}$ & 0.06 & 0.11 & 0.19 & 0.07 & -0.00 & -.06 & $-0.20^{*}$ & 0.06 & -0.00 \\
\hline
\end{tabular}

\section{Discussion}

Findings from this study indicate that children with physical disabilities were more participate in ADL, IADL, craft and artistic activities rather than social, play, sports and winter activities. These findings are consistent with the findings of Law et al. [4], in which children with disabilities have relatively greater participation in personal activities than group and community-based activities. Children with physical disabilities had low participation diversity and intensity in sports. This is because they are affected by physical or institutional, environmental barriers [4]. Damiano et al. [7] suggested the importance of active involvement in daily physical activity as a means to maintain and strengthen the strength and function of children with physical disabilities. However, the level of physical activity involvement of children with physical disabilities in Korea is shown to be worrying.

Sex differences in this study were consistent with studies of activity participation in children without disabilities. For example, a school-aged boy without disabilities participate more frequently in sports, while girl participate more frequently in craft or social activities [8]. There is a difference in participation diversity and intensity according to the age group of children with physical disabilities. Children over the age of 14 had significantly lower scores in the diversity and intensity of participation compared to other age groups. These findings appear to be due to developmentally anticipated differences in child and youth participation patterns.

The higher the disability rating and the fewer the number of multiple disorder, the higher the diversity and intensity of participation except for ADL. Disability rating are divided into six ratings to support education and medical care according to the severity of disabilities based on physical examinations (gross and fine motor functions), cognitive functions, and activity of daily living. The lower the disability rating means that the disability is serious. Improving physical function can provide children with the opportunity to frequently participate in more diverse activities [9]. Therefore, rehabilitation therapy for physical function improvement is important to promote participation of children with physical disabilities.

The higher the family income, the higher the participation intensity in winter activity. The reason is that snow-related activities are likely to relate to family income because they have to pay an entrance fee to use a professional sledding range. There was a significant difference in children's play activities depending on where they live. The reason why indoor playgrounds and trampolines are mainly operated in cities.

This study is meant to analyze the participation patterns of the overall activities of the school-aged children with physical disabilities by expanding the researches focusing on leisure and recreational activities. The limitation of this study was to analyze only the correlations between children's personal variables, family variables and participation patterns. However, in future studies, the structural equations will be used to examine the causal relationship of factors affecting participation.

\section{Conclusion}


This study can provide basic information to understand the participation patterns of schoolage children with physical disability in Korea and help occupational therapists to develop intervention plan enhancing participation.

\section{References}

[1] N. Dahan-Oliel, K. Shikako-Thomas, and A. Majnemer, "Quality of life and leisure participation in children with neurodevelopmental disabilities: a thematic analysis of the literature," Qual Life Res, vol.21, no.3, pp.427-39, (2012) DOI: 10.1007/s11136-011-0063-9.

[2] C. J. Stevenson, P. O. D. Pharoah, and R. Stevenson, "Cerebral palsy-The transition from youth to adulthood, Dev Med Child Neurol,” vol.39, no.5, pp.336-42, (1997) DOI: /10.1111/j.1469-8749.1997.tb07441.x

[3] G. King, M. Law, S. King, P. Rosenbaum, M. K. Kertoy, and N. L. Young, "A conceptual model of the factors affecting the recreation and leisure participation of children with disabilities," Phys Occup Ther Pediatr, vol.23, no.1, pp.63-90, (2003)

[4] M. Law, G. King, S. King, M. Kertoy, P. Hurley, P. Rosenbaum, N. Young, and S. Hanna, "Patterns of participation in recreational and leisure activities among children with complex physical disabilities," Dev Med Child Neurol, vol.48, no.5, pp.337-342, (2006)

[5] L. S. Chiarello, R. J. Palisano, M. N. Orlin, Hui-ju Chang, Denise Begnoche, and M. An, "Understanding participation of preschool-age children with cerebral palsy," J. Early Interv, vol.34, no.1, pp.3-19, (2012)

[6] S. Y. Kim, D. G. Hong, and J. S. Lee, "Validity of the activity participation assessment for school age children,” J Korean Society Occup Ther, vol.26, no.1, pp.119-132, (2018) DOI: 10.14519/jksot.2018.26.1.09

[7] D. L. Damiano, K. Dodd, and N. F. Traylor, "Should we be testing and training muscle strength in cerebral palsy?” Dev Med Child Neurol, vol.44, no.1, pp.68-72, (2002) DOI: $10.1017 /$ s0012162201001682

[8] S. Y. Kim, E. Y. Yoo, M. Y. Jung, S. H. Park, J. S. Lee, and J. Y. Lee, "Reliability and validity of the activity participation assessment for school-age children in Korea," Hong Kong J Occup Ther, vol.28, pp.33-42, (2016) DOI: 10.1016/j.hkjot.2016.08.001

[9] P. Sloper, S. Turner, C. Knussen, and C. Cunningham, "Social life of school children with Down's syndrome," Child Care Heath Dev., vol.16, no.4, pp.235-251, (1990) DOI: 10.1111/j.1365-2214.1990.tb00658.x 
Understanding Activity Participation in Children with Physical Disabilities in Korea

This page is empty by intention. 